\title{
Strategic priorities and accountability for allocating the state budget amid Covid-19 pandemic in Indonesia
}

\section{Nanang Suparman}

Faculty of Social Science and Political Science, UIN Sunan Gunung Djati, Indonesia

Correspondence author email: n.suparman69@gmail.com

\begin{tabular}{|l|l|l|l|l|}
\hline DOI: & Received: & Revised: & Accepted: & Published: \\
10.22437/ppd.v9i1.11640 & 03.01 .2021 & 06.03 .2021 & 02.04 .2021 & 30.04 .2021 \\
\hline
\end{tabular}

\begin{abstract}
This study explains about strategic priorities of state financial management for handling the Covid-19 pandemic in Indonesia. The impact of this pandemic has caused the country's financial posture in the state budget to be unbalanced, where receipts have decreased while in state spending has increased very sharply. Such conditions imply that the state budget deficit's widening exceeds the limit set by the law. The method used in this research method is a descriptive qualitative approach using literature data that can provide analysis of strategies to change the state financial management amid the Covid-19 pandemic. The study concluded that the government's strategic response in abnormal situations is an extraordinary matter with budget allocation priorities aimed at public health and safety, including medical personnel, protection and social safety nets for vulnerable people, and protection among business people. However, it requires accountable supervision, especially for the distribution of social assistance funds with experience prone to corruption practices so that it is not on target.
\end{abstract}

Keywords: Covid-19, State finances, Strategic priorities

JEL Classification: E61, G32, G38

\section{INTRODUCTION}

Covid-19 pandemic in Indonesia continues to add 21,944 new deaths. Task Force (Satgas) Covid-19 announced as of December 30, 2020, the number of infected reached 735,124 people, with the addition per day of 8002 people (Merdeka, 2020). The government takes preventive and curative approaches to suppress the spread of this dangerous disease. The implementation of Large-Scale Social Restrictions (Indonesian: Pembatasan Sosial Berskala Besar = PSBB) policy continues to be extended and tightened supervision and the application of health protocols. Meanwhile, the United Nations urges the international community to take any steps to address Covid-19 (News Wires, 2020). The capacity of countries in the world to face challenges of how to create extraordinary efforts to overcome Covid-19 (Bacq et al., 2020). Mitigation of this health disaster should be the priority of every government globally to the lowest point of transmission and mortality (Walker et al., 2020).

The complexity of the economic impact of Covid-19 threatens global economic resilience and enables an unpredictable economic crisis. They assumed the economic 
impact of this pandemic in shocks due to negative supply conditions (Barua, 2020; Hausmann, 2020; Rahmany, 2021). Many workers are exposed to the virus to stop the production process (McKinsey \& Company, 2020). Widespread contagion globally results in a workforce shortage so that a country's economic and financial infrastructure is under serious pressure. PSBB policies limit population interaction, and they impact reducing production and production distribution flows.

As an illustration, one of Indonesia's manufacturing centers in the Greater Jakarta industrial area stopped production during the first quarter of 2020 following the implementation of PSBB. It has had a very significant impact on output reduction, so that the achievement of purchasing managers index in April 2020 is only 27.5 lower than the achievement in April 2020 of 46.5 (Katadata, 2020). So far, it is known that state revenues from export taxes on manufactured goods are significant for the State Budget. If there is pressure in the form of a decrease in exports can threaten the stability of the posture of the State Budget itself (DetikFinance.com, 2020). A construction modeling the economic impact of the Covid-19 pandemic by Eichenbaum et al. (2020) shows that policies to suppress the virus's spread can save lives; on the other hand, they can exacerbate economic recession because a massive wave of layoffs follows it.

The contraction in economic growth related to the decline in state revenues also occurred globally, with a significant decrease in ratings experienced by almost all member states (International Monetary Fund, 2020). It is worse than the global financial crisis before. Related to gross domestic product, an assumption about the decline in Gross Domestic Product (GDP) In 2020 globally could touch the figure of more than 8 Trillion US Dollars Dollar (McKibbin \& Fernando, 2020). Observing the worsening economic impact, the government established the country's financial policy with a priority strategy approach in terms of financing and in terms of revenue by reallocating from various sources of the State Budget that are not urgent, the government bond payment (SUN) and revising the legal basis with the redefinition of the budget deficit in the State Finance Law. The basis for strategic policy refocusing and reallocating the government budget against the background of abnormal conditions in the form of the Government Regulation in Lieu of Law (Peraturan Pemerintah Pengganti Undang-Undang or Perppu) No. 1 of 2020 (Kacaribu, 2020). Reorganize the priority scale of central and local government spending with an analysis of spending that has been budgeted since the beginning of the work program by refocusing on the budget in the health, social, and business sectors. Refocusing is also driven by declining assumptions of state revenue (Kacaribu, 2020).

Budget allocation is not limited to the capital expenditure budget to operational expenditures only, but other efforts can be carried out by reducing or moratorium on infrastructure projects, trimming on routine expenditures such as official travel costs, meeting expenditures, technical guidance, organizing ministry training, and institutions that collect significant budget allocations. Definition of state finances should be the frame of reference for managing the budget of a particular program (Atmadja, 1986; Musgrave, 1989; Suparmoko, 2013; Ulbrich, 1993). This article describes the government's response from the perspective of state financial management in handling Covid-19. State financial management related to the State Budget includes revenue sources, spending mechanisms, central and regional fiscal arrangements, and fiscal capacity and liabilities, both short and long term. 


\section{METHODS}

The study of strategic priorities and accountability of government budget allocation amid the Covid-19 pandemic is designed with qualitative academic literature survey approach methods. This study rests on secondary data in document analysis with validity that can be accounted for so that its analysts are considered credible (Bowen, 2009). The data obtained through the search efforts of various sources both from the documents of ministries, state and international institutions, the results of research academics fiscal policy as well as the source of writings from journals and various mass media both print and electronic to describe the financial management of countries affected by the pandemic.

In the research stage that the authors did: first, the authors found the problem of pressure on the posture of the State Budget as a result of the spread of Covid-19 that caused economic contraction two quarters in a row so that Indonesia entered into recession; secondly collect secondary data on the up to date development of Covid-19 in Indonesia, the economic impact it causes, and the reallocation of government budgets obtained from scientific publications and official information from the Ministry of finance; third, classify and select data relevant to the country's financial management for handling Covid-19; fourth, data analysis by interpreting the main study of budget financing priority strategies in the field of public health, various stimulus, and allocation for national economic recovery; the fifth concludes this study.

\section{RESULTS AND DISCUSSION}

\section{Priorities for public health and safety protection}

The success in managing the state budget can be measured through the achievement of sustainable fiscal policy. However, the emergency impact of the Covid19 pandemic has brought tremendous pressure on the spending side. To maintain the posture of the State Budget is not included in the critical condition, the government designed a policy to strengthen the revenue side by issuing Government Securities (SUN) in US Dollar (US Bond) denominations with a total nominal of USD 4.3 Billion. Consisting of USD1.65 Billion for 10.5-year tenors, USD1.65 Billion for 30.5-year tenors, and USD 1 Billion for 50-year tenors (Puspasari, 2020). Important early anticipation of handling Covid in overcoming the lack of budget (Rosewicz et al., 2020).

Under the authority given by Law No. 24 of 2002 on Government Securities, the Minister of Finance determines the results of SUN sales transactions in foreign currencies as Table 1.

Table 1. Transaction selling Government Securities (SUN) in US Dollar denomination

\begin{tabular}{lccc}
\hline Series & RI1030 & RI1050 & RI0470 \\
\hline Tenor & 10.5 years & 30.5 years & 50 years \\
Due date & October 15 2030 & October 15 2050 & April 15 2070 \\
Pricing date & & April 6 2020 & \\
Issue date & April 15 2020 \\
Nominal issued & USD 1.65 Billion & USD 1.65 Billion & USD 1 Billion \\
Coupon rate & $3.850 \%$ & $4.200 \%$ & $4.450 \%$ \\
Yield & $3.900 \%$ & $4.250 \%$ & $4.500 \%$ \\
Price & $99.573 \%$ & $99.150 \%$ & $99.009 \%$ \\
\hline
\end{tabular}

Source: Ministry of Finance of the Republic of Indonesia

The issuance of USD Bonds will be used to meet the State Budget's financing in 
general, including costs for COVID-19 handling and recovery efforts. State budget financing through market mechanisms is an effort by the government to continue implementing fiscal policy positively, disciplined, and sustainable amidst volatile global economic conditions (Chapman, 2016). On the other hand, it also illustrates responsive fiscal policy to support 3 (three) government priority programs in handling COVID-19, namely handling health problems, providing social safety nets, and supporting the business world, especially MSMEs. A priority scale of financing for urgent programs is needed to balance the State Budget (Purba et al., 2021; Rossen \& Gayer, 2008).

The state budget all-out support for handling the spread of Covid-19 includes testing, tracing, and treatment. The timely preparation of the 2021 State Budget indicates the government's serious efforts amid the country's difficult financial situation. DIPA/KL submission process and allocation list of Transfer to regions and village funds (TKDD) state budget 2021 earlier to support the handling of Covid-19, providing social protection, economic recovery, and various strategic development priorities. Determination of Covid-19 transmission has even reached the level of family clusters, social restrictions in the long term, and widespread, resulting in a domino effect of pressure on economic activities (Suparman et al., 2020). Handling Covid-19 and public health recovery are preconditions for economic recovery and reform implementation. The curative step is to provide vaccines to suppress and break the chain of Covid-19 spread (Rahman, 2021). On the other hand, the government continues to improve access to quality health services by paying attention to supporting health resources, national health insurance, strengthening central and regional coordination, and developing health resilience preparedness systems (Worldbank.org, 2020).

The release of Covid-19 gave rise to the government's strategic response by prioritizing spending in the health and safety sector, including medical personnel, to maximize the handling of Covid-19 outbreaks. With the publication of the minister of finance's official letter addressed to all Ministries/Institutions to relocate non-priority expenses posts. Based on the Ministry of Finance's Initial Study, the number of nonpriority budgets that can be relocated for handling Covid-19 health disasters reaches 5 Trillion to 10 trillion, including criteria including funds that are still blocked, remaining tender funds, and canceled activities. In terms of expenditure for goods, the expense that will be reallocated is not urgent expenditure, and the activities are recommended to be reduced. The expenditure of such goods includes the expense for official travel both at home and abroad, expense related to meetings involving large numbers of participants both at home and overseas. Extraordinary conditions and full of uncertainty, demanding that the government respond quickly through the arrangement of an adaptive state budget to deal with economic turbulence impacts of the pandemic.

As of the end of February 2020, domestic travel spending was only realized at Rp 2.5 Trillion or contracted by $7.5 \%$ compared to the same period last year. Foreign service travel spending only realized Rp200 billion, contracted $42.8 \%$ compared to the same period last year. Overall, the official travel spending ceiling in 2020 reached Rp43.7 Trillion, which can be prioritized for handling Covid-19. In terms of capital expenditures, expenditures that are not a priority and there is no alliance because it is still blocked, still in the tender process, until the rest of tenders for capital goods procurement will also be reallocated. Many of the remaining tenders and funds were canceled at the Ministry of Public Works and Housing due to changing situation conditions. All of these were reallocated for Covid-19 handling. The revised time of 
ministries/agencies spending is accelerated from the usual 5 days to 2 days to accelerate budget reallocation.

Significant pressure on the spending side encourages the reformatting of the State Budget in connection with the soaring urgent need to follow up on the health impacts of Covid-19, expand the social safety net for affected communities, as well as domestic economic recovery efforts. The government needs precise managerial accounting practices (Granof et al., 2016; Hansen \& Mowen, 2007). The review of the State Budget structure is carried out through Presidential Regulation No. 54 of 2020, then again adjusted to Presidential Regulation No. 72 of 2020.

Refocussing and reallocating the budget as a tactical step by the Ministry of Finance in supporting the handling of health disasters that require a large and immediate budget. The terminology of the task force handling the spread of the Covid-19 pandemic under the National Disaster Management Agency (BNPB) is included in the preparation of operational budget needs prepared as in Table 2.

Table 2. Refocussing and reallocating the budget to handle the spread of Covid-19.

\begin{tabular}{lrc}
\hline Allocation recipients & Amount & Notes \\
\hline Ministry of Health & $3.14 \mathrm{~T}$ & some \\
Deputy for Emergency Management BNPB & $27.68 \mathrm{M}$ & full \\
Deputy for Logistics BNPB & $106.79 \mathrm{M}$ & some \\
Task Force & $12.78 \mathrm{M}$ & full \\
National Armed Forces of Indonesia Headquarters & $82 \mathrm{M}$ & full \\
\hline
\end{tabular}

Source: Ministry of Finance of the Republic of Indonesia

In the context of efforts to save the community from the dangers of Covid-19, the Spokesperson of the Task Force handling Covid-19 explained that there had been quite a lot of progress achieved until the eleventh month period the distribution of vaccines throughout the region with storage by the target set. The implementation of vaccination will begin immediately without any constraints. The availability of ready-made vaccines, for vaccine raw materials available 15 million doses of Sinovac production, followed by the procurement of 50 million Novava vaccines, then the procurement of 50 million doses of Astra Zeneca, 50 million Pfizer vaccines, as well as a collaboration of Cvac-Gavi produced 54 million doses of vaccine as the last layer of inventory.

In addition to the curative approach, the government continues its preventive approach by preventing the spread of the Covid-19 virus. The general evaluation of social restrictions proved to suppress the spread, especially accompanied by increased public discipline. Standard Operating Procedure (SOP), which has been done in the form of testing, tracking, and treatment, will continue to be intensified with the target population target is even greater according to or exceed the indicators set by the World Health Organization (WHO). Operationally, officers at various levels of the Indonesian National Military, police, and involving various community organizations are working hard to monitor and improve the tracking system to ensure that new cases do not arise.

Government policy in handling the covid-19 pandemic prioritizes handling the health and safety of citizens, including medical personnel and medics. The main indicator of the policy is to prevent deaths, especially for frontline medics handling covid-19. Any efforts to prevent the transmission of Covid-19 must be accompanied by a level of public discipline in compliance with health protocols that so far have to be continuously improved. 


\section{Priorities for social protection.}

Vulnerable communities affected by Covid-19 are increasingly experiencing deterioration. Before the Covid-19 cases spread, their conditions have been difficult, especially economically, now the purchasing power of vulnerable people is weakening, if such circumstances are not immediately handled can trigger a spike in poverty, conditions that easily trigger chaos then the government has channeled a number of budgets of Rp. 205.20 trillion to minimize the influence of Covid-19 from purchasing power. Details of the budget for the allocation of social protection Rp 203.90 trillion helped the board sector in the form of housing incentives MBR (Low-Income Communities) Rp 1.3 trillion. In essence, the policy of strengthening purchasing power serves as a barrier to accelerating the economic impact on people with declining purchasing power. Social safety net policies targeting grass-root communities in pandemic conditions are considered appropriate and fair measures. Still, technical problems in terms of accuracy of policy target data and the urgency of aid distribution time become an unsolved problems. On several occasions, the House of Representatives has reminded the government to improve social assistance distribution's overall management.

The community's purchasing power or the broader context as demand is related to the number of products available in increasing or decreasing conditions, followed by price adjustments as a reflection of the community's expenditure side. The picture of demand in Indonesian society is more than $60 \%$ of GDP in consumption and distribution. The community's economic structure tends to be low income, thus rationally the right step of the government with the priority of providing social protection first. Social assistance to cover basic needs at least targets the most vulnerable layers of socioeconomic communities due to COVID-19. The social protection scheme became urgent to be immediately distributed with a budget ceiling of Rp 203.9 trillion, followed by the MBR housing incentive scheme (Badan Kebijakan Fiskal, 2020).

The Hope Family Program (Indonesian: Program Keluarga Harapan (PKH)) continued and expanded its recipient target by improving its effectiveness database to be more accountable for the budget of Rp37.4 trillion. The Kartu Sembako program, with a budget of $\mathrm{Rp} 43.6$ trillion, to reduce household costs, is given electricity discounts for $450 \mathrm{VA}$ and $900 \mathrm{VA}$ with a budget ceiling of Rp 6.9 trillion. The social assistance program (Indonesian: Bansos) for non-Jakarta, Bogor Depok Tanggerang Bekasi (Jabodetabek) clusters amounting to $\mathrm{Rp} 32.4$ trillion, specifically for Jabodetabek Bansos disbursed Rp 6.8 trillion, other important programs ranging from Direct Cash Assistance (Indonesian: Bantuan Langsung Tunai (BLT)) following the Village Fund Rp31.8 trillion and Workers Card of Rp20 trillion. Improving the demand side of society as a targeted policy amid the ongoing pandemic crisis is crucial to create economic resilience in the community. So in this context, budget management reflects the politics of pro-poor budgets, balancing the health sector and the economic sector, and balancing brake and gas control. 
Table 3. Economic stimulus for handling Covid-19 in Indonesia

\begin{tabular}{|c|c|c|c|}
\hline No & Stimulus forms & Types of stimulus & Description and stimulus objectives \\
\hline \multirow{5}{*}{1} & \multirow{5}{*}{$\begin{array}{l}\text { Fiscal } \\
\text { Stimulus }\end{array}$} & $\begin{array}{l}\text { Relaxation of income } \\
\text { tax }(\mathrm{PPh}) \text {, article } 21\end{array}$ & $\begin{array}{l}\text { Relaxation for workers in the manufacturing } \\
\text { sector for } 6 \text { months. Assisting worker liquidity } \\
\text { in related sectors. }\end{array}$ \\
\hline & & $\begin{array}{l}\text { Relaxation of income } \\
\text { tax }(\mathrm{PPh}) \text { article } 22\end{array}$ & $\begin{array}{l}\text { Imports for } 6 \text { months for } 19 \text { specific sectors. } \\
\text { Giving cash flow space as switching cost } \\
\text { compensation. }\end{array}$ \\
\hline & & $\begin{array}{l}\text { Reduction in income } \\
\text { tax }(\mathrm{PPh}) \text { article } 25 \\
\text { by } 30 \% \text {. }\end{array}$ & $\begin{array}{l}\text { Valid for } 6 \text { months intended for certain sectors. } \\
\text { Giving cash flow space as switching cost } \\
\text { compensation. }\end{array}$ \\
\hline & & $\begin{array}{l}\text { Income tax restitution } \\
\text { (PPn) }\end{array}$ & $\begin{array}{l}\text { Accelerated for } 6 \text { months for } 19 \text { specific sectors. } \\
\text { Helps the liquidity of the company. }\end{array}$ \\
\hline & & $\begin{array}{l}\text { PPh Final } \\
\text { Government } \\
\text { Regulations no. } 23 \\
\text { year } 2018 .\end{array}$ & $\begin{array}{l}\text { Relaxation for } 6 \text { months on PPh Final } \\
\text { Government Regulations No. } 23 \text { of } 2018 \text {. Easing } \\
\text { the burden on entrepreneurs, especially in the } \\
\text { MSME sector }\end{array}$ \\
\hline \multirow{4}{*}{2} & \multirow{4}{*}{$\begin{array}{l}\text { Non Fiscal } \\
\text { Stimulus }\end{array}$} & $\begin{array}{l}\text { Simplification of } \\
\text { limited bans for } \\
\text { export }\end{array}$ & $\begin{array}{l}\text { Aims to improve the smooth export and } \\
\text { competitiveness of export products. } \\
\text { Completeness of Health Certificate and V-Legal } \\
\text { is no longer a document of export requirements } \\
\text { unless required by the exporter }\end{array}$ \\
\hline & & $\begin{array}{l}\text { Simplification of } \\
\text { limited bans for } \\
\text { import }\end{array}$ & $\begin{array}{l}\text { Aims to improve the smooth import and } \\
\text { availability of raw materials }\end{array}$ \\
\hline & & $\begin{array}{l}\text { Acceleration of } \\
\text { export-import } \\
\text { percentage for } \\
\text { Reputable Traders }\end{array}$ & $\begin{array}{l}\text { Differentiating the practice of services / } \\
\text { supervision to } 625 \text { major customs partners } \\
\text { (MITA) and } 109 \text { authorized economic operator } \\
\text { (AEO) companies. }\end{array}$ \\
\hline & & $\begin{array}{l}\text { Acceleration of } \\
\text { export-import } \\
\text { percentage in general. }\end{array}$ & $\begin{array}{l}\text { Entrepreneurs can manage through the } \\
\text { mechanism of the National Logistics Ecosystem. }\end{array}$ \\
\hline \multirow{5}{*}{3} & \multirow{5}{*}{$\begin{array}{l}\text { Financial } \\
\text { Sector } \\
\text { Stimulus }\end{array}$} & $\begin{array}{l}\text { Banking policy for } \\
\text { Supporting economic } \\
\text { growth stimulus } \\
\text { including MSME } \\
\text { debtors }\end{array}$ & $\begin{array}{l}\text { Carried out to encourage optimization of } \\
\text { banking intermediation function. Credit quality } \\
\text { assessment/financing/provision of other funds } \\
\text { refers to indicators in the form of the accuracy of } \\
\text { principal and/or interest payments for loans up to } \\
\text { Rp10 billion. }\end{array}$ \\
\hline & & $\begin{array}{l}\text { Restructuring policy } \\
\text { of MSME debtors in a } \\
\text { more flexible way. }\end{array}$ & $\begin{array}{l}\text { Maintaining financial system stability. Banks } \\
\text { can restructure all credit/financing regardless of } \\
\text { credit ceiling limits or types of debtors, } \\
\text { including MSME debtors. The quality of } \\
\text { credit/financing carried out by the restructuring } \\
\text { is determined smoothly after the restructuring. }\end{array}$ \\
\hline & & Encouraging THE & Supporting economic growth, especially the \\
\hline & & $\begin{array}{l}\text { Empowerment of } \\
\text { MSMEs }\end{array}$ & $\begin{array}{l}\text { Micro, Small and Medium Enterprises (MSMEs) } \\
\text { sector. Restructuring MSME credit/financing. }\end{array}$ \\
\hline & & Workers Incentive & $\begin{array}{l}\text { Relaxation incentives in the Program Social } \\
\text { Security Administering Agency Employment to } \\
\text { workers to anticipate contracting the corona. }\end{array}$ \\
\hline
\end{tabular}

Source: Regulation of the Minister of Finance No.23/PMK.03/2020. 


\section{Priorities for businesses support}

The economic impact of Covid-19 is not only on vulnerable communities but the business community is also hit hard enough that the production process is stopped partially or even largely stopped altogether. During the economic crisis in 1998, MSMEs can survive and are proud to be the last economic defense. In the covid-19 pandemic, MSMEs conditions are experiencing different situations. The production process became abnormal by more than $70 \%$. In idle conditions due to the supply side of raw materials distorted. The rapid supply of imported products from foreign producer countries in line with the decrease in the number of local manufacturing production impacts the application of PSBB makes the problems of the business world more complex.

At the lower-middle-class level, the decline in purchasing power is triggered by a decrease in income due to the pandemic generating so that people's wiggle room becomes very limited or, even in some areas, is partially locked down. Contribution of spending power or the level of public consumption at the economic level can also experience braking based on consideration of vigilance or concern affected by Covid-19 infection.

The impact of PSBB throughout the region caused economic activity to decrease dramatically from indicators of oil and gas demand declining world oil prices were hit at the lowest point. The use of toll road services shrank by almost $80 \%$. All modes of transportation are shrinking the number of transportation users is very significant both modes of air transportation, land transportation, and sea transportation

The problem of depreciation of business capital due to the pressure of the company's cash flow is sought through the channel with fiscal disbursements for the MSME sector in the form of MSME credit stimulus, including the budget ceiling of Rp. 34.15T is then distributed through the national banking distribution mechanism, channeling through rural banks and financing companies. The benefits received by the community of beneficiaries include a moratorium on installments and interest subsidies for Micro and Small Enterprises of 6\% for the first three months and 3\% for the next three months, as well as Medium Enterprises of 3\% for the first three months and 2\% for the next three months. The loan allocation of 6.47T was distributed through KUR, UMi, Mekaar, and Pawnshop with the ease received in delays in principal installments and interest subsidies for KUR, UMi, Mekaar, and pawnshops for six months. Credit allocation of Rp. 0.49T is distributed through Online, Operations, Farmers, LPDB, LPMUKP, and Local Government MSMEs. The convenience received in the form of relaxation is given a $6 \%$ interest subsidy for six months.

The accumulation of convenience received by the community through the variant of economic stimulus program can trigger innovations of micro-enterprises and MSMEs. Or at least as a cushion of the social safety net where the pull or breaking of community activities due to the pandemic does not result in the state entering a very severe scenario.

Social restriction policies to suppress the increasingly progressive trend of Covid19 transmission are colluding negatively with the normality of corporate activities. The results of a recent survey BPS (2020) described that $40 \%$ of the companies surveyed had ceased operations with capacity reduction variants covering working hours, machinery, and workforce. In companies both Small Medium Enterprises (MSMEs) and Medium Enterprises (UMB) that can still survive to operate faced with the same problems that are crucial, among others, $80 \%$ are faced with a decrease in demand as a 
consequence of customers/clients who are also affected by Covid-19.

Various academic studies and interpretation of survey results related to the impact of COVID-19 on the business world's existence can be used as a measure or criteria to analyze the benefits of economic stimulus programs as part of the grand design of national economic recovery holistically. The government needs to immediately evaluate the social assistance package that has been distributed, including economic stimulus in the business sector.

Conceptually evaluation provides an assessment of goals' achievement, not evaluating the objectives (Suparman et al., 2019). The target specification (goals) is then set because the goals are the criteria for the program's success. It must be stated specifically to obtain the benchmark criteria. These goals are often only stated in general or with a long-term scope, and sometimes even counter-productive and not related to program activities. Furthermore, to optimize the objectives of budget management policy for those affected by Covid-19 within the program evaluation framework, it is necessary to institutionalize evaluators who act as containers, as a process, as behavior, and as a tool to achieve goals.

Concerning the setting of the objectives of the evaluation of the budget management impact of covid-19 and to find out the level of evaluator elements to the main objectives of the evaluation, all evaluator components consisting of the Audit Board of Finance (BPK), the Audit Board of Finance and Development (BPKP), inspectorate general of the Ministry of Finance, Inspectorate General of the Ministry of Social Affairs and Inspector general of the relevant Ministry must understand comprehensively the main objectives of the policy of evaluating the management of the state budget impact of Covid-19, namely to validate (audit) the financial governance of the state in the pandemic to be aligned and not contrary to the State Finance Law as the basis of positive law.

The specifications of budget management policy evaluation activities for handling socioeconomic impacts carried out by evaluators contain more detailed objectives. In this context, the objectives of evaluators are: 1) to understand, analyze and provide an assessment of the development of budget absorption for handling affected by a pandemic from each evaluator. 2) Formulate policies related to the governance of the new budget version of Covid-19 conducted by stakeholders of the Ministry and Institutions leading the sector handling Covid-19 at the central and regional levels. 3) Mapping the performance of each of the main unit agencies mandated to evaluate the policy of changes in budgeting management.

The Wave of Covid-19 pandemic has impacted the joints of social life with rapid changes that were previously unexpected and not expected. The decline in economic activity in most countries in the world, including Indonesia. Policy formulation to spawn extraordinary government efforts in its handlers requires a valid and accurate database as a precondition so that the national economic recovery program during this pandemic can be achieved with a high success rate. Cross-sectoral evaluation across Ministries and Institutions handling the impact of Covid-19 on small and large businesses is experimental statistics to provide cutting-edge indicators (an early indicator) about businesses affected by the Covid-19 pandemic. Monitoring and evaluation can be done through an online survey platform to capture information about social phenomena and at the same time quantify data related to the condition of the company in the midst of a pandemic that can be seen in multi aspects, including operational, labor aspects, income aspects, difficulties faced, adaptation level, building optimism, to the assistance needed. 


\section{CONCLUSIONS AND RECOMMENDATIONS}

\section{Conclusions}

This study explains the strategic priorities and accountability in allocating social assistance regarding the progression of the COVID-19 pandemic, which has led to new and growing death rates. The adverse effect on the national economy caused the downturn in the small and medium enterprises segment, triggered by the community's declining purchasing power. The state budget's impact in contraction in economic growth per quarter in a row led to an economic recession, and a potential economic crisis could be possible. Based on these precarious conditions, the Government of Indonesia has issued an extraordinary policy of handling this epidemic through a new strategic approach to state budget management that strengthens the spending side's acceptance and relevance in line with the handling of Covid-19.

On the budget revenue side, gathering from various sources of reallocation of central government spending, savings on state spending from non-urgent budget posts, and capital expenditures are not priorities. The current budget deficit is inevitable and is predicted to exceed the law's maximum threshold on state finances. In an abnormal state budget situation during the pandemic, the government can take extraordinary steps to formulate and implement policies to widen the budget deficit to save the economy and financial system. Extraordinary measures are necessary to secure the state budget accompanied by accountable and transparent evaluation to avoid economic crisis.

\section{Recommendations}

This study recommends that the Central Government through the Ministry of Finance must make various efforts to protect public health and take tactical measures in budget governance in an effort to minimize the impact of Covid-19 on the economic downturn of the community, MSME sector, and Industry in general so that social assistance continues to be extended.

The next budget allocation is focused on fiscal stimulus, non-fiscal stimulus, and fiscal stimulus. Limited data access in the middle of the pandemic by accessing secondary data in 2019 and data in 2020. It is recommended to other researchers to conduct follow-up research to monitor and evaluate the 2 nd and $3^{\text {rd }}$ semester and year 2021 economic growth and its impact on the economic sector in general.

\section{REFERENCES}

Atmadja, A.P.S. (1986). Mekanisme pertanggungjawaban keuangan negara: suatu tinjauan yuridis. Jakarta: Gramedia.

Bacq, S., Geoghegan, W., Josefy, M., Stevenson, R., \& Williams, T. A. (2020). The COVID-19 Virtual Idea Blitz: Marshaling social entrepreneurship to rapidly respond to urgent grand challenges. Business Horizons, 63(6), 705-723.

Badan Kebijakan Fiskal. (2020). Pemerintah Upayakan Bantuan Sosial Efektif dan Tepat Sasaran di Masa Pandemi Covid-19. Badan Kebijakan Fiskal. https://fiskal.kemenkeu.go.id/baca/2020/05/03/150626860665310-pemerintahupayakan-bantuan-sosial-efektif-dan-tepat-sasar

Barua, S. (2020). COVID-19 pandemic and world trade: Some analytical notes. MPRA Paper 99761, University Library of Munich, Germany.

Bowen, G. A. (2009). Document analysis as a qualitative research method. Qualitative Research Journal, 9(2), 27.

BPS. (2020). Analisis Hasil Survey Dampak Covid-19 Terhadap Pelaku Usaha. Jakarta: 
BPS.

Chapman, B. (2016). China's nine-dashed map: Continuing maritime source of geopolitical tension. Geopolitics, History, and International Relations, 8(1), 146168.

DetikFinance.com. (2020). Sri Mulyani Akui Virus corona Jadi Ancaman Fatal Ekonomi RI. Detikfinance. https://finance.detik.com/berita-ekonomi-bisnis/d4905982/sri-mulyani-akui-virus-corona-jadi-ancaman-fatal-ekon

Eichenbaum, M. S., Rebelo, S., \& Trabandt, M. (2020). The macroeconomics of epidemics. National Bureau of Economic Research.

Granof, M. H., Khumawala, S. B., Calabrese, T. D., \& Smith, D. L. (2016). Government and not-for-profit accounting: Concepts and practices. John Wiley \& Sons.

Hansen, D. R., \& Mowen, M. M. (2007). Managerial accounting 8th Edition. Ohio (USA): Thomson South-Western.

Hausmann, R. (2020). Flattening the COVID-19 curve in developing countries. World Economic Forum. https://www.weforum.org/agenda/2020/03/flattening-thecovid-19-curve-in-developing-countries/

International Monetary Fund. (2020). Real GDP Growth: Annual Percent Change. International Monetary Fund. https://www.imf.org/external/datamapper/ NGDP_RPCH@WEO/OEMDC/ADVEC/WEOWORLD

Kacaribu, F. (2020). Media Briefing: Program pemulihan Ekonomi Nasional. Kemenkeu. https://www.kemenkeu.go.id/media/15116/media-briefing-kabkf.pdf

Katadata. (2020). Bapennas: Daya Beli Masyarakat Hilang Rp $362 T$ Akibat Pandemi Corona. Katadata. https://katadata.co.id/agustiyanti/finansial/5ef09effcdd5c/ bappenas-daya-beli-masyarakat-hilang-rp-362-t-akibat-pandemi-coro

McKibbin, W. J., \& Fernando, R. (2020). The global macroeconomic impacts of COVID-19: Seven scenarios. CAMA Working Paper 19/2020. https://papers.ssrn.com/sol3/papers.cfm?abstract_id=3547729

McKinsey \& Company. (2020). Consumer Sentiment and Behaviour Continue to Reflect the Uncertainty of The Covid-19 Crisis. McKinsey \& Company. https://www.mckinsey.com/business-functions/marketing-and-sales/ourinsights/a-global-view-of-how-consumer-behavior-is-changing-amid-covid-19\#.

Merdeka. (2020). Data terkini Jumlah Virus Corona di Indonesia. Merdeka.com https://www.merdeka.com/peristiwa/data-terkini-jumlah-korban-virus-corona-diindonesia.html

Musgrave, R. A. (1989). Public finance in theory and practice. McGraw-Hill.

News Wires. (2020). UN chief decries "horrifying" rise in domestic violence amid virus lockdown. New Wires. http://www.france24.com/en/20200406-un-chief-decrieshorrifying-rise-in-domestic-violence-amid-viruslockdown

Purba, B., Albra, W., Rahman, A., Purba, P. B., Nugraha, N. A., Irawati, H. M., Syafii, A., Damanik, E. O. P., \& Fajrillah, F. (2021). Ekonomi Publik. Jakarta: Yayasan Kita Menulis.

Puspasari, R. (2020). Transaksi Penjualan Surat Utang Negara Dalam Denominasi US Dollar Sebesar USD 4,3M Melalui SEC-Registered Shelf Take Down. Kemenkeu. https://www.kemenkeu.go.id/publikasi/siaran-pers/siaran-pers-transaksipenjualan-surat-utang-negara-dalam-denominasi-us-dollar-sebesar-usd4-3-miliarmelalui-sec-registered-shelf-take-down/

Rahman, Y. A. (2021). Vaksinasi Massal Covid-19 sebagai Sebuah Upaya Masyarakat dalam Melaksanakan Kepatuhan Hukum (Obedience Law). Khazanah Hukum, 
3(2), 80-86

Rahmany, G.M. (2021). Social Development Through International Relations. Khazanah Sosial, 3(1), 22-32.

Rosewicz, B., Maynard, M., \& Fall, A. (2020). States take early steps to manage COVID-19 budget fallout. The PEW Charitable Trust. https://www.pewtrusts.org/ en/research-and-analysis/articles/2020/04/24/states-take-early-steps-to-managecovid-19-budget-fallout

Rossen, H.S. \& Gayer, T. (2008). Public Finance. McGraw Hill

Suparman, N., Chandra, D., \& Sari, A. L. (2019). Bureaucratic Behavior in the Implementation of Capital Expenditure Budget in the Office of Public Work and Spatial Planning of Sumedang Regency. Jurnal Bina Praja: Journal of Home Affairs Governance, 11(1), 99-109.

Suparman, E.N., Sakti, F.T., \& Anwar, H.S. (2020). Covid-19: Kebijakan Mitigasi Penyebaran dan Dampak Sosial Ekonomi di Indonesia. Digital Library UIN Sunan Gunung Djati. http://digilib.uinsgd.ac.id/30820/1/Dr\%20ENGKUS\%2C \%20Dkk- Artikel\%20KTI\%20-2020..pdf

Suparmoko, M. (2013). Keuangan Negara, Dalam Teori dan Praktek (6th ed.). Yogyakarta: BFEE UGM

Ulbrich, H. (1993). Public Finance in Theory and Practice. Thompson Learning.

Walker, P. G. T., Whittaker, C., Watson, O. J., Baguelin, M., Winskill, P., Hamlet, A., Djafaara, B. A., Cucunubá, Z., Mesa, D. O., \& Green, W. (2020). The impact of COVID-19 and strategies for mitigation and suppression in low-and middleincome countries. Science.

Worldbank.org. (2020). Prospek Ekonomi Indonesia, Juli 2020: Jalan Panjang Pemulihan Ekonomi. World Bank. https://www.worldbank.org/in/country/ indonesia/publication/indonesia-economic-prospect

(C) 2021 by the authors. Licensee JPPD, Indonesia. This article is an open-access article distributed under the terms and conditions of the Creative Commons Attribution (CC BY) license (http://creativecommons.org/licenses/by/4.0/). 